\title{
Screening of Soybean Genotypes for Waterlogging Stress Tolerance and Understanding the Physiological Mechanisms
}

\author{
Khadeja Sultana Sathi (D), Abdul Awal Chowdhury Masud (D, Maliha Rahman Falguni, \\ Naznin Ahmed, Khussboo Rahman $\mathbb{D}$, and Mirza Hasanuzzaman
}

Department of Agronomy, Faculty of Agriculture, Sher-e-Bangla Agricultural University, Dhaka 1207, Bangladesh

Correspondence should be addressed to Mirza Hasanuzzaman; mhzsauag@yahoo.com

Received 12 October 2021; Accepted 28 December 2021; Published 12 January 2022

Academic Editor: Ganesh Nikalje

Copyright $\odot 2022$ Khadeja Sultana Sathi et al. This is an open access article distributed under the Creative Commons Attribution License, which permits unrestricted use, distribution, and reproduction in any medium, provided the original work is properly cited.

\begin{abstract}
Waterlogging is a common form of abiotic stress that severely impedes global soybean production. Targeting this issue, an experiment was carried out at Sher-e-Bangla Agricultural University during August-November 2019 to screen out the waterlogging tolerance and yield performances of selected soybean genotypes. The experiment was laid out in a completely randomized design (CRD) with three replications consisting of 2 water levels (control and waterlogging) and 12 genotypes (Sohag, BARI Soybean-5, BINAsoybean-1, BINAsoybean-2, BINAsoybean-3, BINAsoybean-5, BINAsoybean-6, SGB-1, SGB-3, SGB-4, SGB-5, and GC-840). On the 15th day after sowing, plants were exposed to waterlogging for 12 days. Waterlogging remarkably declined the growth and yield of all the soybean genotypes compared to control. Reduced plant height, relative water content, above-ground fresh and dry weight, SPAD value, leaf area, number of leaves, branches, pods, seeds pod ${ }^{-1}$, 100 -seed weight, and seed yield plant ${ }^{-1}$ were observed under waterlogging stress. Conversely, mortality rate and electrolyte leakage were increased under the same condition. The waterlogged plants showed delayed flowering and maturity compared with the control plants. However, among the 12 genotypes, Sohag, BARI Soybean-5, GC-840, BINAsoybean-1, and BINAsoybean-2 showed better waterlogging tolerance. These genotypes showed a greater number of adventitious roots in the base of their stem, which probably helped plants to thrive under waterlogging conditions.
\end{abstract}

\section{Introduction}

Plants are randomly revealed to unfavorable environmental circumstances, which are named as abiotic stresses, for instance, waterlogging, drought, salinity, heavy metal stress, high temperature, nutrient stress, radiation, and environmental pollution [1], and as a result pose a serious ultimatum to crop production. Waterlogging in cultivated areas is a common abiotic stress which has severe influences on the composition and production of soybean $[2,3]$ and most crops' species worldwide $[4,5]$. Excess rainfall, tides, floods, storms, and lack of adequate drainage facilities are the causes of waterlogging stress in plants [6].

Gas exchanges between root systems and porous spaces in waterlogged soils are restricted due to diffusion resistance to oxygen as its diffusion is 10,000 times lower in water, relative to air [7]. Primarily, waterlogging stress causes hypoxic $\left(\mathrm{O}_{2}\right.$ deficient $)$ condition, which affects aerobic respiration. Over the course of time, the stress switched to an anoxic $\left(\mathrm{O}_{2}\right.$ absent $)$ condition, which causes inhibition of respiration [8], limitation of energy, deposition of noxious compounds (e.g., lactate), and loss of carbon (through the loss of ethanol from the roots) [9]. Oxygen is needed for the division of cells, development of cells, respiration, absorption, and transportation of nutrients in plants. Due to flooding stress, plants experienced chlorosis, necrosis, defoliation, growth reduction, reduced nitrogen $(\mathrm{N})$ fixation, yield loss, and death of plant at both vegetative and reproductive stages [10]. Flooding stress-induced ethanol accumulation imposes adverse impacts on various processes [11]. Voesenek and Bailey-Serres [12] stated that waterlogging stress posed $\mathrm{O}_{2}$ deficiency in the soil, which triggered 
the accumulation of ethylene, phytotoxic mineral nutrients $\left(\mathrm{Mn}^{2+}\right.$ and $\left.\mathrm{Fe}^{2+}\right)$ and also the production of reactive oxygen species (ROS) and reactive nitrogen species (RNS) in plants. Flooding stress-induced production of ROS, which is responsible for oxidative stress as well as cellular damages like lipid peroxidation, damaged nucleic acid, downregulation of enzymes, and activation of programmed cell death [13]. Many countries in Asia experience flooding stress during the rainy season. In Bangladesh, the waterlogging condition is common in kharif season due to flash floods and/or heavy rainfall. Soybean crops are usually intolerant to waterlogging stress [14]. In different flooding durations, soybean plants reacted significantly different to flooding stresses [3]. In soybean, waterlogging stress switched aerobic respiration towards anaerobic. Anaerobic respiration triggers alcoholic $\left(\mathrm{C}_{2} \mathrm{H}_{5} \mathrm{OH}\right)$ fermentation by generating waterlogged-inducible proteins that help in the generation of $\mathrm{NAD}^{+}$and convey sharp increment activity of alcohol dehydrogenase $(\mathrm{ADH})$ in soybean plants [15]. According to Oosterhuis et al. [16], waterlogging can diminish the yield of soybeans by 17 to 43 percent at the vegetative growth stage and by 50 to 56 percent at the reproductive stage.

For optimal production under stress condition, it is essential to identify soybean cultivars that are tolerant to flooding. In developing soybean varieties that can withstand pregermination conditions of low oxygen during waterlogging, the available genotypic variation could be exploited. The criteria for the choice and development of waterlogging resistant soybean are appropriate screening methods, morphophysiological characteristics correlated with tolerance, and the identification of promising genotypes. Thus, improving the genetic resources of soybean and developing waterlogged-tolerant genotypes is of great importance. Studies on this aspect have not yet been done extensively. Therefore, this experiment has been designed to screen out waterlogging tolerance and yield performances of selected soybean genotypes.

\section{Materials and Methods}

2.1. Climatic Condition, Treatments, and Design. The experiment was conducted in kharif-II season when a temperature around $30^{\circ} \mathrm{C}$ was prevailed in the months of July to September and started falling from October to November 2019. There were 12 genotypes of soybean and 2 water level conditions as control and waterlogging. Each treatment was compared to its corresponding control. There were two sets of pots in the experiment: one set was for taking growth and physiological data and another was for measuring yield data. Waterlogging treatments were started at 15 days after sowing (DAS). The root zone was submerged and water level was maintained at $5 \mathrm{~cm}$ above the soil surface in the pot. After 12 days of waterlogging, the water was removed and allowed to come to field capacity. The experiment was laid out in a completely randomized design with three replications.

2.2. Crop Husbandry. Ten seeds were sown in each $16 \mathrm{~L}$ plastic pots. Gap-filling was performed in some pots when some seeds of soybean failed to germinate. Thinning was done to maintain 3 seedlings for yield set. Mulching was done by loosening the soil very often to maintain moisture. Irrigation was given in control plants maintaining field capacity. Other intercultural operations were performed as required.

\subsection{Data Collection}

2.3.1. Crop Growth Parameters. Before starting the treatment, the total number of plants per pot was counted, which was denoted as $\mathrm{Ni}$, and again after the completion of treatment duration, the total number of plants per pot was counted, which was denoted as $\mathrm{Np}$. The mortality rate was calculated using the following formula of Anee [17]:

$$
\text { mortality rate }(\%)=\frac{\mathrm{Ni}-\mathrm{Np}}{\mathrm{Ni}} \times 100 \text {. }
$$

Plant height was recorded from the ground level to the highest tip of the leaf by a measuring scale at 25 DAS. The numbers of trifoliate leaves and branches plant ${ }^{-1}$ were counted once after the completion of the vegetative growth of plants at 50 DAS. For measuring leaf area, firstly, leaf images were taken by a digital camera at 32 DAS, and then the area was calculated using ImageJ software (version $1.53 n)$.

For plant fresh weight (FW), three sample plants were uprooted from each pot randomly and thoroughly washed under running tap water then weighed in an electric balance. After recording the FW, the samples were dried in an electric oven maintaining $80^{\circ} \mathrm{C}$ for $48 \mathrm{~h}$ then weighed. Both the $\mathrm{FW}$ and DW data were taken at 20 DAS. Data of three plants were averaged for all the parameters.

2.3.2. Physiological Parameters. Five leaves were randomly selected from each pot. Each leaflet was measured with atLEAF (FT Green LLC, USA) as atLEAF value at 30 DAS. The total chlorophyll ( $c h l$ ) content was then averaged and calculated by translating the atLEAF value into SPAD units. Relative water content (RWC) was recorded at 20 DAS following the procedure of Barrs and Weatherley [18]; leaf laminas of fully developed leaves were separated from randomly selected plants. Whole leaf discs were weighed as FW and then floated in Petri dishes with distilled water and kept in a dark place. After $24 \mathrm{~h}$, the leaf discs were weighed again by removing excess surface water and considered as turgid weight (TW). Dry weights (DW) of leaves were measured after drying at $80^{\circ} \mathrm{C}$ for $48 \mathrm{~h}$. Finally, using the following formula, RWC was calculated:

$$
\text { RWC }(\%)=\frac{F W-D W}{T W-D W} \times 100 .
$$

Electrolyte leakage (EL) was measured at 20 DAS following the method of Zhang et al. [19]. To measure EL, $0.5 \mathrm{~g}$ leaf samples was put in a Falcon tube with $15 \mathrm{ml}$ distilled water. The Falcon tubes were then incubated in a water bath at $40^{\circ} \mathrm{C}$ for about $1 \mathrm{~h}$. After cooling, electrical conductivity $\left(\mathrm{EC}_{1}\right)$ was recorded with an electrical conductivity meter. Samples were again incubated in an Autoclave machine for 
about $1 \mathrm{~h}$ and electrical conductivity $\left(\mathrm{EC}_{2}\right)$ were measured with an EC meter (HI98301, Hanna, USA) after cooling the samples. Electrolyte leakage was calculated using the following formula as described by Anee [17]:

$$
\mathrm{EL}(\%)=\frac{\mathrm{EC}_{1}}{\mathrm{EC}_{2}} \times 100 \text {. }
$$

\subsubsection{Observation of Phenotypes of Adventitious Root and} Plants. Adventitious roots of waterlogged plants were taken at $25 \mathrm{DAS}$, and pictures were taken with a digital camera. Comparative pictures of plants were taken two times: one at the vegetative phase (25 DAS) and another at the reproductive phase (75 DAS).

2.3.4. Yield and Yield-Contributing Parameters. The total number of pods plant ${ }^{-1}$ was counted from the three plants and then averaged. Ten pods from each pot were selected, and seeds were counted from each individual pods and then averaged as number of seeds pod ${ }^{-1}$. Harvested seeds were sundried, and then clean 100 seeds were weighed with an electric balance. After separating seeds from stover, that was weighed as seed yield plant ${ }^{-1}$.

2.4. Statistical Analysis. Data accumulated from different parameters were subjected to analysis using CoStat v.6.400 [20] and one-way analysis of variance (ANOVA). For finding out mean differences among the replications, Fisher's least significant difference (LSD) test at the 5\% level of significance was applied. Pearson's correlation analysis was done using SPSS v.27 [21].

\section{Results and Discussion}

\subsection{Crop Growth Parameters}

3.1.1. Mortality Rate. Mortality rates varied in several genotypes. Among all the genotypes, the lowest mortality rate was observed in BARI Soybean-5 (9\%), whereas the highest was observed in the genotype SGB-3 (43\%) followed by SGB4 (36\%), BINAsoybean-2 (35\%), BINAsoybean-5 (32\%), BINAsoybean-6 (28\%), BINAsoybean-1 (28\%), BINAsoybean-3 (28\%), SGB-5 (21\%), SGB-1 (17\%), GC-840 (15\%), and Sohag (11\%) (Figure 1). All the control plants survived in this experiment. In this experiment, death of soybean genotypes due to imposition of waterlogging was observed. Few genotypes showed severe death, and few showed some tolerance. Survival rate varied in soybean plants at genotypes and duration-dependent manner [3]. While working on 40 soybean genotypes under different levels of waterlogging stress $(3,6,9,12$, and 15 days), Wu et al. [3] observed the survival rate of plants. They reported $96.1 \%$ plant survival rate (PSR) in all the genotypes at 3 days of waterlogging at V5 stage of plants. At 6 days of waterlogging, 31 genotypes exhibited tolerant response with 70\% PSR; at 9 days, 12 genotypes exhibited tolerant response with $46.7 \%$ PSR; at 12 days, only 3 genotypes exhibited tolerant response with
34.9\% PSR; and at 15 days, all genotypes exhibited sensitive responses and PSR was $21 \%$ at V5 stage.

3.1.2. Plant Height. A sharp reduction of plant height was observed upon exposure to waterlogging stress in comparison to the control condition (Table 1). The lowest reduction in plant height was observed in waterlogged BINAsoybean-2 that was $2 \%$ when compared to the control condition. The highest reduction in plant height was observed in waterlogged SGB-1, which was $34 \%$ in comparison with the control condition. Upon exposure to waterlogging, the reduction in plant height ranged between 2 and 33\% in other genotypes when compared with their respective control plants. The waterlogging-induced decrease in plant height was noticed in soybean [22]. Waterlogging leads to a hypoxic situation, which caused damage to the roots as there prevailed insufficient water, minerals, nutrients, and hormones. This inadequacy of nutrients and water uptake leads to shoot damage, and finally, a reduction in plant height was observed [23]. Waterlogging can restrict the ability of plant to assimilate carbon and nitrogen by inhibiting carbon and nitrogen metabolism. Reduction of $\mathrm{CO}_{2}$ assimilation: photosynthesis rate significantly decreases upon exposure to waterlogging; eventually, plant showed stunted growth. These might result in a decrease in plant's height in this study. Besides, the plant cannot uptake the proper amount of nutrients $\mathrm{N}, \mathrm{P}$, and $\mathrm{K}$, which results in nutrient deficiency symptoms and, finally, reduction of shoot length [24].

3.1.3. Number of Leaves Plant ${ }^{-1}$. When exposed to waterlogging, the number of leaves plant ${ }^{-1}$ showed a decreasing manner when compared to the control plants (Table 1). The lowest reduction in leaf number was observed in waterlogged SGB-1 (3\%) when compared to the control condition. The highest reduction in leaf number was observed in waterlogged BINAsoybean-6 (57\%) in comparison with the control condition. Upon exposure to waterlogging, the reduction in leaves number ranged between 4 and $42 \%$ in other genotypes when compared with their respective control plants. Flooding leads to a decline in crop growth, net assimilation rate, and leaf expansion, and the ultimate outcome was a reduction of leaf number and leaf area in soybean crops [25].

3.1.4. Number of Branches Plant ${ }^{-1}$. When exposed to waterlogging, the number of branches plant ${ }^{-1}$ showed a decreasing manner when compared to the control plants (Figure 2). The lowest reduction in branches number was observed in waterlogged BINAsoybean-1 (19\%) followed by BARI Soybean-5 (20\%), GC-840 (20\%), and Sohag (24\%) when compared to the control condition. The highest reduction in branch number was observed in waterlogged BINAsoybean-6 (50\%) and SGB-3 (50\%) in comparison with the control condition. Upon exposure to waterlogging, the reduction in branch numbers ranged between 28 and $45 \%$ in other genotypes when compared with their respective control plants. The stunted plant leads to a lower number of branches. Miura et al. [26] also reported waterlogging for 


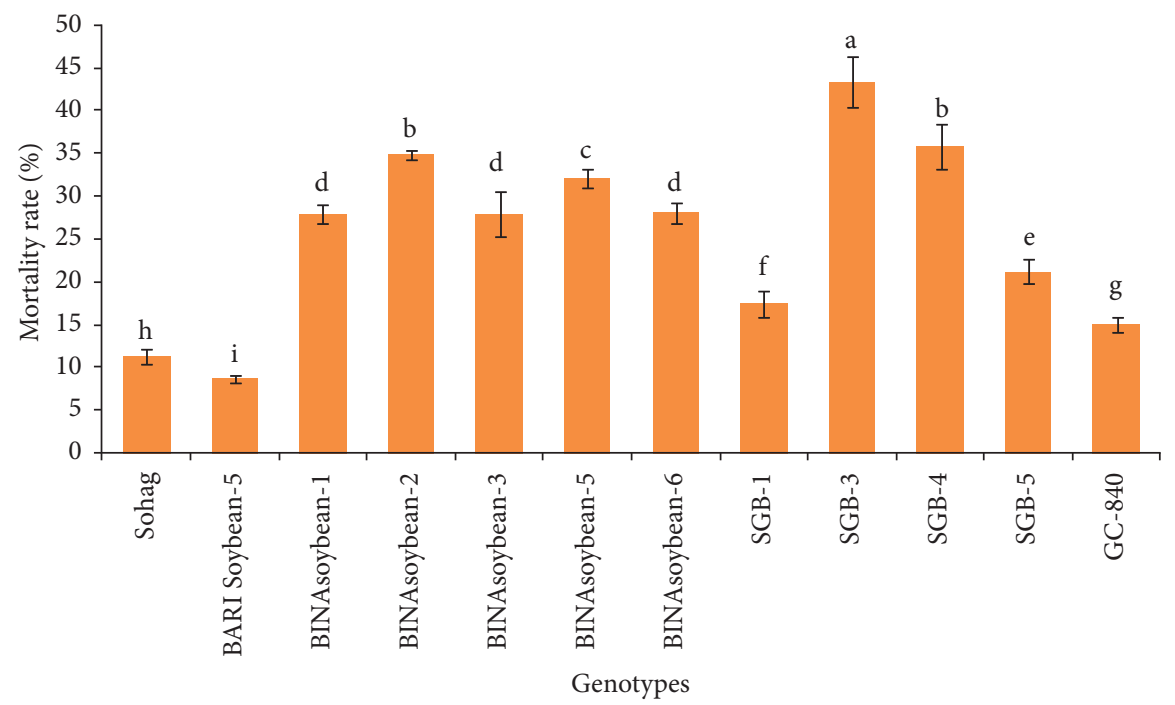

Figure 1: Effect of waterlogging stress on the mortality rate of different soybean genotypes at 12 days after treatment. For each treatment, the mean $( \pm S D)$ was determined from three replicates. Different alphabets on the bars indicate significant difference at $P \leq 0.05$ after mean comparison by Fisher's LSD test.

21 days in soybean, which resulted in a significant reduction in number of branches of soybean plants. Decrease in branch number in response to several stresses in soybean was also reported by several studies [27-29].

3.1.5. Leaf Area. A sharp reduction of leaf area was observed upon exposure to waterlogging stress in comparison with the control condition (Table 1). The lowest reduction of leaf area was observed in waterlogged BARI Soybean-5 (2\%) followed by Sohag (3\%), BINAsoybean-2 (4\%), and BINAsoybean-1 (9\%). The highest reduction was observed in SGB-5 (16\%). Upon exposure to waterlogging, the reduction of leaf area ranged between 10 and $14 \%$ in other genotypes when compared with their respective control plants. Leaf area of different soybean genotypes decreased due to waterlogging stress (Table 1), which is evidenced by many authors [30, 31]. Similar outcomes were observed in some other crops like mungbean [32], barley [33], sesame [34, 35], and green gram [36].

3.1.6. Above-Ground Fresh and Dry Weight Plant ${ }^{-1}$. Upon exposure to waterlogging, above-ground FW plant $^{-1}$ reduced when compared to their control plants. The lowest reduction in plant FW was observed in waterlogged BARI Soybean-5 (6\%) followed by Sohag (8\%) and BINAsoybean$2(13 \%)$ in comparison with control. The highest decline in plant FW was observed in waterlogged SGB-4 (43\%) in comparison with the control condition (Figure 3(a)). Upon exposure to waterlogging, the reduction in plant FW ranged between 17 and $40 \%$ in other genotypes when compared with their respective control plants.

The remarkable decline was recorded in above-ground dry matter weight plant $^{-1}$ when exposed to waterlogging condition. The lowest reduction in plant DW was observed in waterlogged Sohag, which was $11 \%$, when compared to the control condition. The highest reduction in plant DW was observed in waterlogged SGB-3 (65\%) in comparison with the control condition. Upon exposure to waterlogging, the reduction in plant DW ranged between 8 and $62 \%$ (Figure 3(b)) in other genotypes when compared with their respective control plants.

Waterlogging-induced reduction in FW and DW was found in soybean in different studies $[37,38]$. Research works showed that waterlogging affects $c h l$ and reduce the content of chl and resulting reduction of photosynthetic process and the decrease in the rate of photosynthesis that inhibited plant growth and accumulation of biomass [39]. Under waterlogging, the phytology and catabolism of plants are disrupted, restricting stomatal conductance, the transition of gases, and metabolism of $\mathrm{CO}_{2}$. Reduction of $\mathrm{CO}_{2}$ entering the leaf reduced transpiration, leading to wilting of the leaves, and decreased chl content as a result lower dry matter accumulation [40], which result greatly in decline of FW and then DW. The reduction of dry matter accumulation in the current findings may be due to a decrease in water absorption and inhibition of photosynthetic processing and synthesis of carbohydrates. The decrease in photosynthesis was due to the decrease in available $\mathrm{CO}_{2}$ through stomatal closure, combined effects of leaf water, osmotic capacity, transpirational rate of stomatal conductance, RWC of leaf, and biochemical constituents, such as photosynthetic pigments, protein, and carbohydrates [41, 42]. Several scientists recorded that flooding stress reduced shoot DW of maize [43], green gram [36], and mungbean [32, 44].

\subsection{Physiological Parameters}

3.2.1. SPAD Value. SPAD reading showed lower value in the leaves of waterlogged plants when compared with the control plants. The lowest reduction was observed in waterlogged BARI Soybean-5 (12\%) in waterlogged plants 


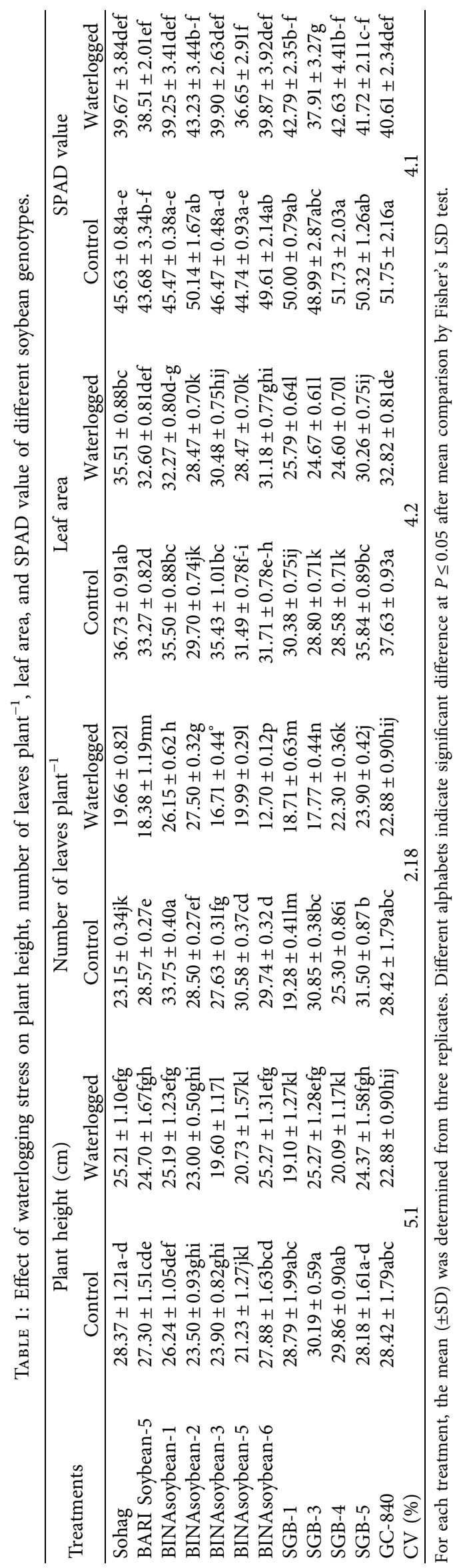




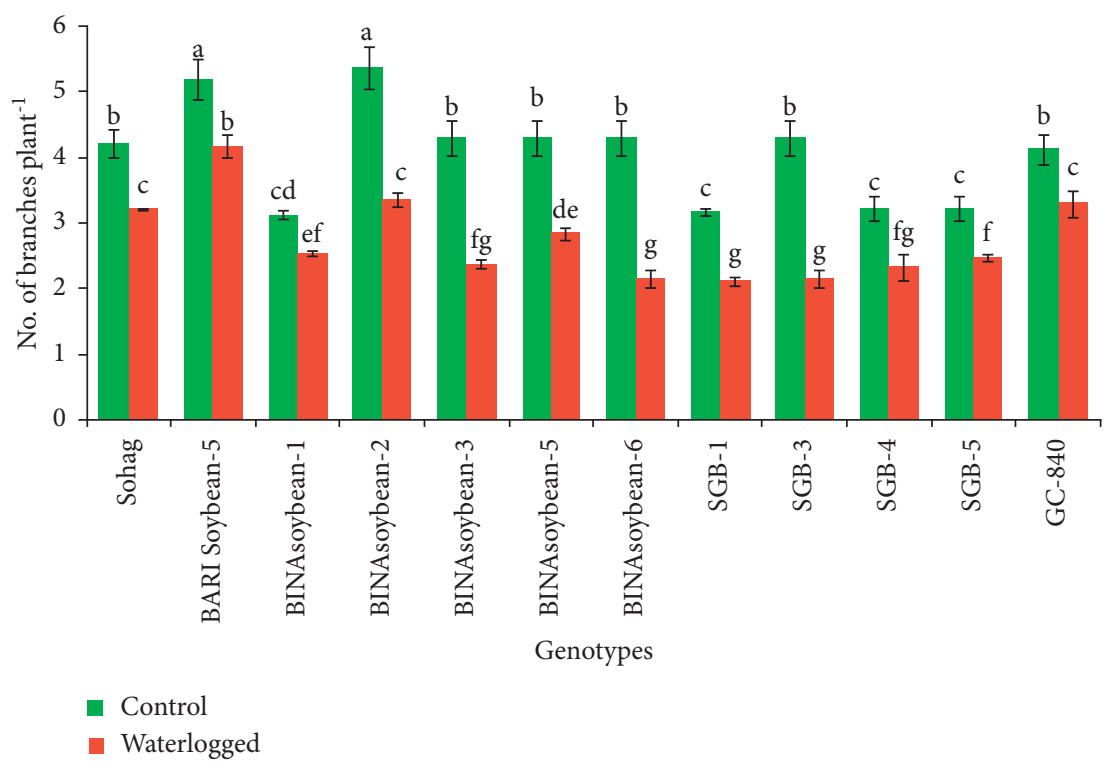

FIGURE 2: Effect of waterlogging stress on number of branches plant ${ }^{-1}$ of different soybean genotypes. For each treatment, the mean $( \pm$ SD) was determined from three replicates. Different alphabets on the bars indicate significant difference at $P \leq 0.05$ after mean comparison by Fisher's LSD test.

when compared to control plants. The highest reduction was observed in waterlogged SGB-3 $(23 \%)$ in waterlogged plants when compared to control plants. Upon exposure to waterlogging, the reduction in SPAD value ranged between 13 and $22 \%$ in other genotypes when compared with their respective control plants (Table 1). Soybean responses to waterlogging are sensitive and endeavoring. The soybean leaves' color appeared from green to yellow after $24 \mathrm{hr}$ waterlogging stress, which is doubted to be the decrease of chl content in soybean leaf. The author observed leaf color variation after 3-day waterlogging as there a significant reduction in chl content was observed [3]. SPAD reading, which is the indicator of chl content of leaf, decreased due to waterlogging stress and the percent reduction varied upon genotype to genotype (Table 1). Waterlogging in soybeans exhibits a decline in activity in photosynthesis [45]. Tian et al. [43] showed that SPAD value reduced $10-38 \%$ in KY16 variety and $5-30 \%$ in DMY1 variety of maize due to waterlogging.

3.2.2. Relative Water Content. When exposed to waterlogging, plants exhibited reduction in leaf RWC (Figure 4). The lowest reduction in leaf RWC was observed in waterlogged BARI Soybean-5 (17\%) and the highest reduction were in waterlogged BINAsoybean-5 (42\%) in comparison with the control condition. The reduction ranged between 18 and $41 \%$ in other genotypes when compared with their respective control plants. Relative leaf water content was found to be a crucial factor in assessing plant tolerance to osmotic stress caused by waterlogging. In our study, waterlogging leads to a significantly reduced RWC content in the several genotypes of soybean plants (Figure 4). Reduction in leaf RWC indicates an insufficient supply of water for cell expansion [46]. Despite the excess quantity of water available under waterlogged conditions, RWC leaves were reduced by soybean plants. This may be due to the prevalence of hypoxia or anoxia that inhibited the permeability of the root [40] and as a result, leaf wilting symptoms were found on plants. The corresponding decrease in RWC due to waterlogging was also observed in mungbean [32] and sesame [34].

3.2.3. Electrolyte Leakage. Electrolyte leakage was increased upon exposure to waterlogging in several genotypes of soybean plants (Figure 5). Electrolyte leakage was enhanced with increasing stress levels as compared to the control. The highest increase was observed in waterlogged BINAsoybean-1 (260\%) and the lowest increase was in waterlogged BINAsoybean-5 (29\%) followed by GC-840 (34\%) and Sohag (35\%) in contrast to control. Upon exposure to waterlogging, the increase in EL ranged between 51 and $111 \%$ in other genotypes. Waterlogged BINAsoybean-1 and BINAsoybean-6; waterlogged BINAsoybean-3, SGB-1, and SGB-4; and waterlogged BARI Soybean-5, BINAsoybean-5, and control BINAsoybean-2, SGB-4 showed no significant difference among them. Electrolyte leakage was increased upon exposure to waterlogging in several genotypes of soybean plants (Figure 6). Due to waterlogging stress, cell membrane became disorganized, which increased the generation of ROS and metabolic toxicity [47]. The membrane injury increased with the increasing duration of waterlogging stress in pigeon pea $[5,48]$.

3.3. Root Phenotypes. Morphological acclimation to waterlogging in soybean emerges to adventitious root formation. The least number of adventitious roots was observed in SGB4, SGB-3, and SGB-1, and the rest of the genotypes showed a quite better number of adventitious roots. Among them, GC- 


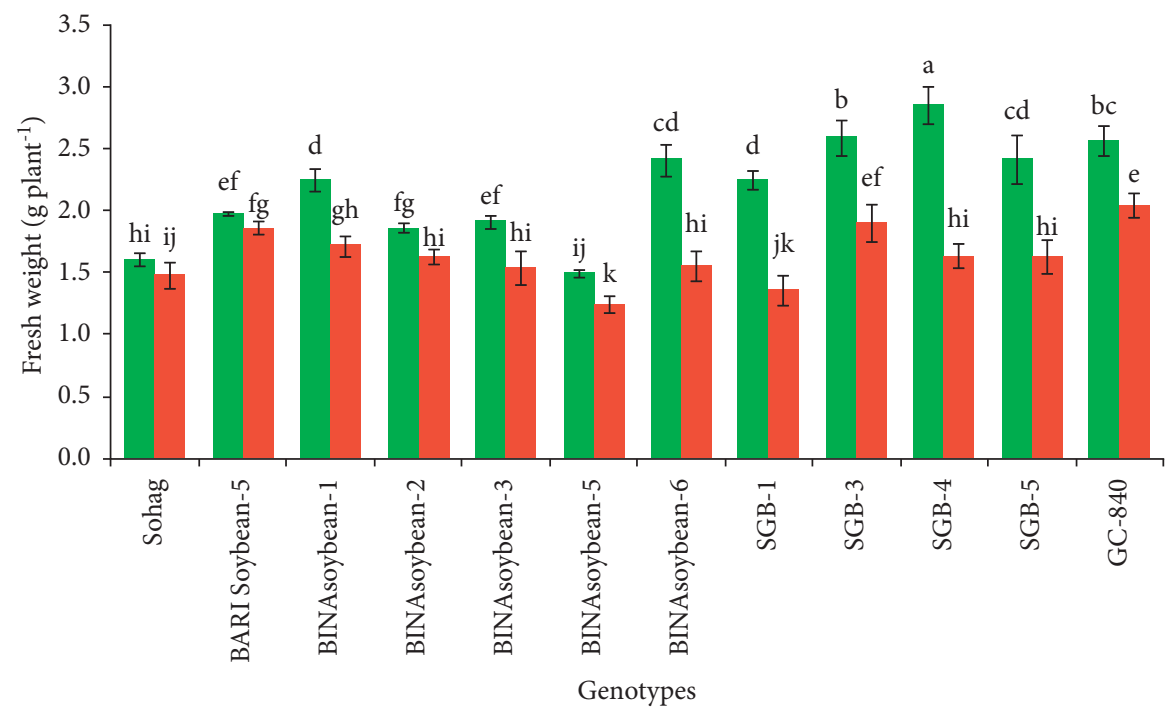

- Control

- Waterlogged

(a)

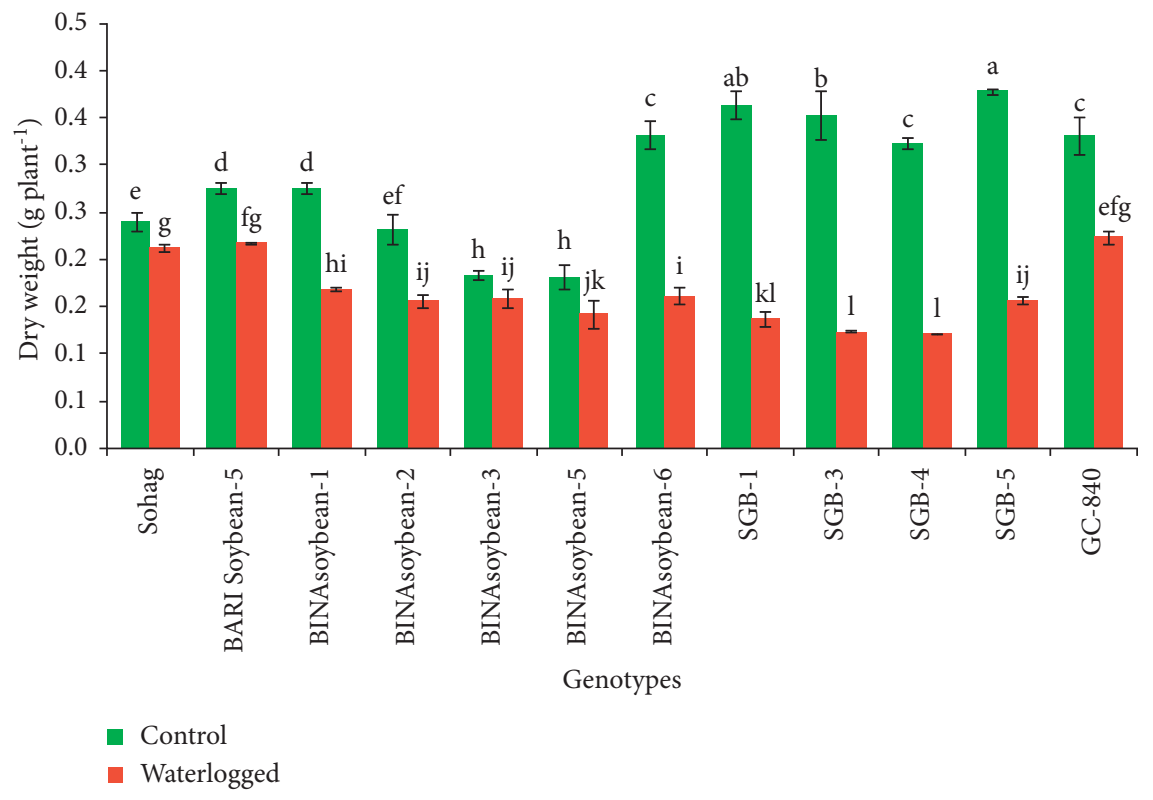

(b)

Figure 3: Effect of waterlogging stress on above-ground fresh (a) and dry (b) weight plant ${ }^{-1}$ of different soybean genotypes. For each treatment, the mean $( \pm \mathrm{SD})$ was determined from three replicates. Different alphabets on the bars indicate significant difference at $P \leq 0.05$ after mean comparison by Fisher's LSD test.

840 showed a higher number of adventitious roots (Figure 6). Waterlogging caused injury to roots owing to cellular anoxia; furthermore, root meristems exhibited susceptibility $[49,50]$. Uptake of water and nutrients failed due to damaged roots. Bacanamwo and Purcel [51] stated that soybean plants showed morphological acclimatization under waterlogging stress to avoid water loss by declining area of leaf and inducing adventitious root formation. They also stated that leaf expansion was not occupied with the accumulation of carbohydrates in the leaf of waterlogged plants. Usually, the carbohydrate used for leaf expansion may be translocated to the roots to generate adventitious roots. One of the main adaptation responses under waterlogging stress is adventitious root formation $[44,52]$. Adventitious roots of soybean under waterlogging stress exploited rupture of cortex cells, creating aerenchyma used as pores for $\mathrm{O}_{2}$ transferring to roots, being a plant adaptive mechanism under these stress conditions [38]. Our experiment also supported the that waterlogging resulted in higher number of adventitious roots in tolerant genotypes. Adventitious roots have not been found in soybean control plants, which is supported by other studies [22]. 


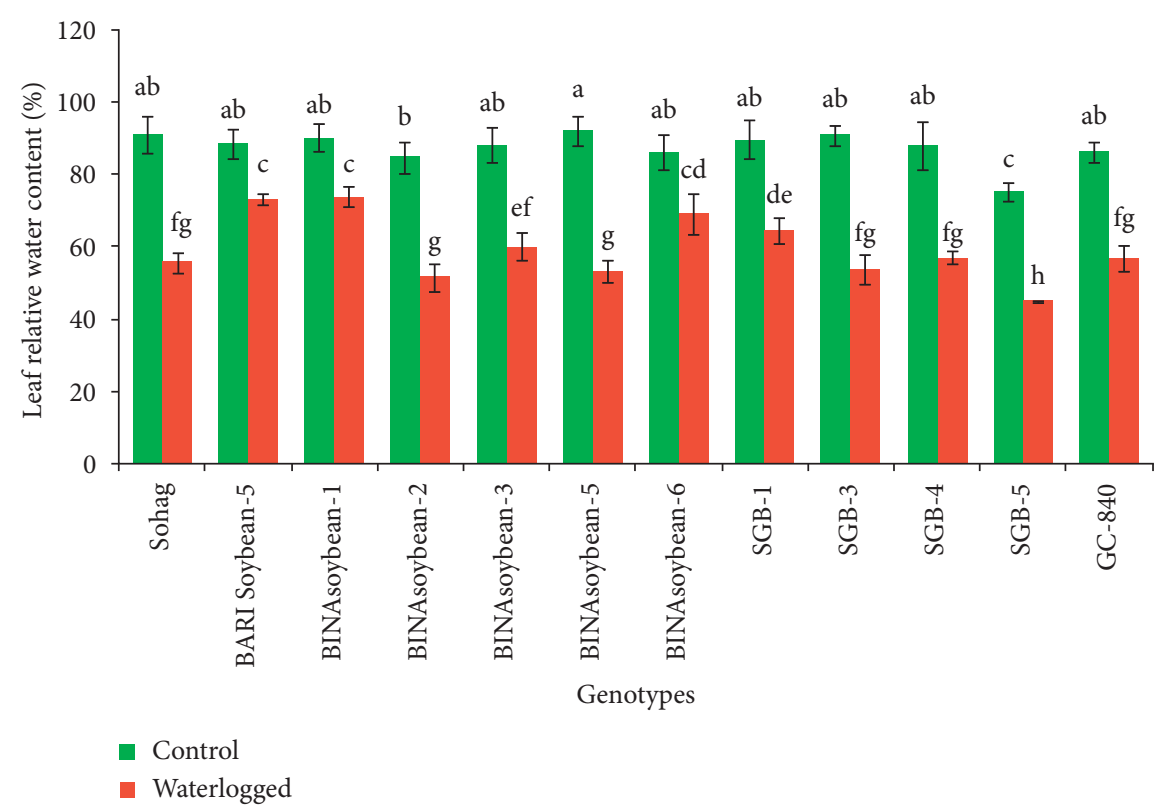

FIGURE 4: Effect of waterlogging stress on leaf relative water content (RWC) of different soybean genotypes. For each treatment, the mean $( \pm S D)$ was determined from three replicates. Different alphabets on the bars indicate significant difference at $P \leq 0.05$ after mean comparison by Fisher's LSD test.

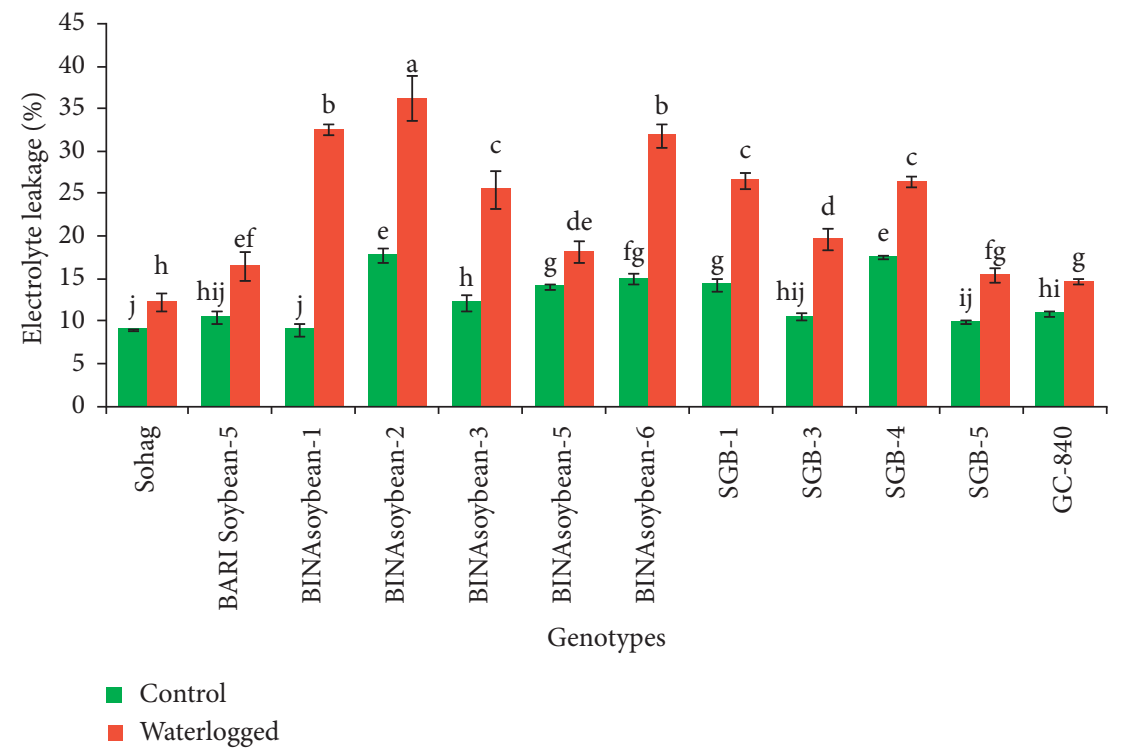

FIGURE 5: Effect of waterlogging stress on electrolyte leakage of different soybean genotypes. For each treatment, the mean $( \pm$ SD) was determined from three replicates. Different alphabets on the bars indicate significant difference at $P \leq 0.05$ after mean comparison by Fisher's LSD test.

3.4. Phenotypic Comparative Observation. In this study, a visible appearance was observed under control and waterlogged plants. Plants displayed a decrease in height compared to their control plants. Death of plants was also observed due to waterlogging stress (Figure 7). Waterlogging for 12 days at the vegetative stage caused delayed flowering and maturity in all the genotypes when compared with their control plants (Figure 8), which is supported by the study of Kuswantoro [53]. This author carried out an experiment with 16 soybean lines, including 2 check varieties (Lawit and
Sinabung), exposing waterlogging to plants after 21 days of planting till harvesting. In his study, he observed that days to flowering and days to maturing of the genotypes were longer in the flooding condition than the control condition. The variety Sinabung and Lawit generally bore flower by 35 and 40 days and became mature by 88 and 84 days, respectively [54]. Kuswantoro [53] observed that days to flowering and days to maturity were delayed by 46,49 days and 98 , 100 days, respectively in Sinabung and Lawit variety. The lengthier days to flowering are supposedly due to the plant 


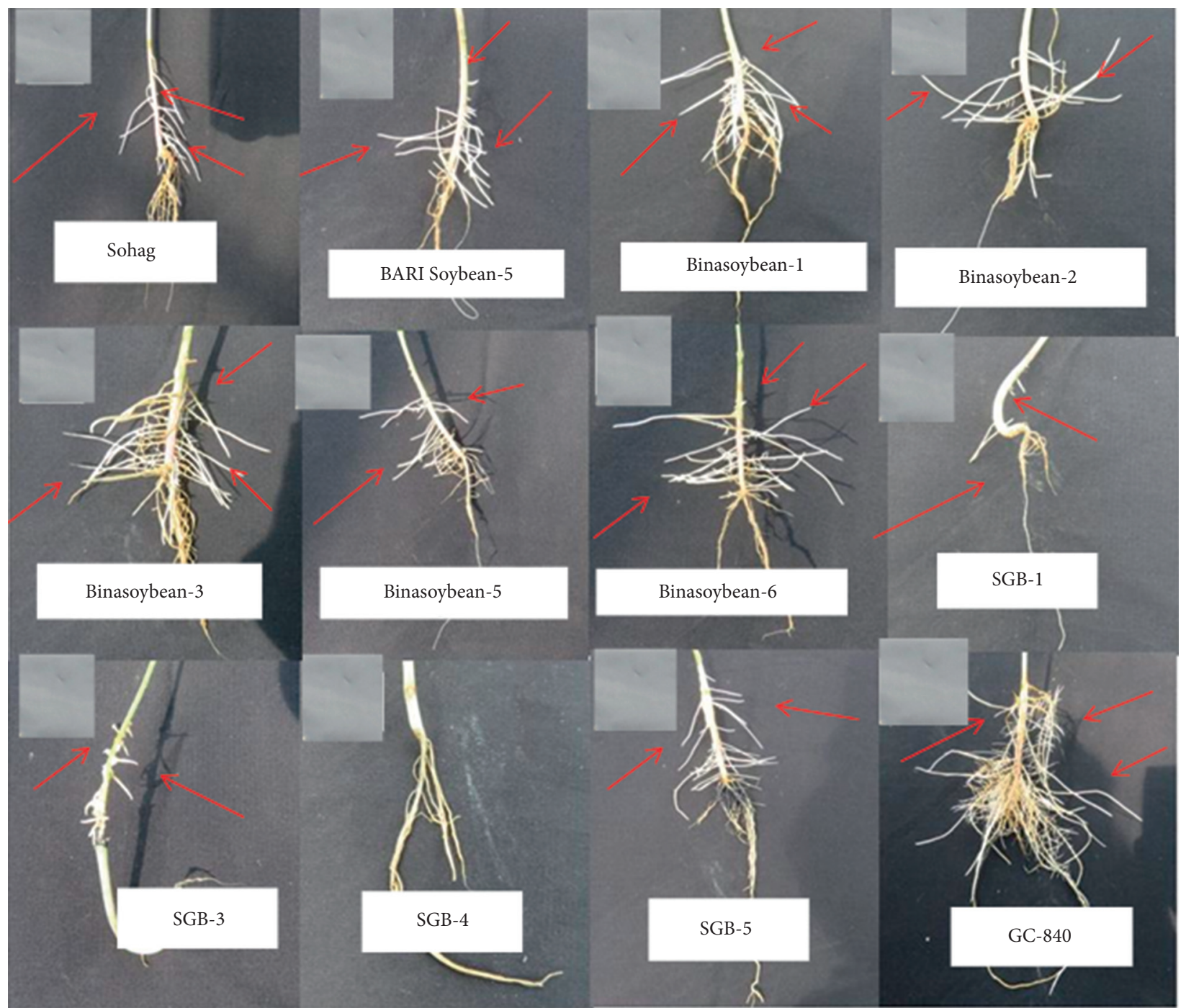

FIGURE 6: Adventitious root formation of different soybean genotypes under waterlogging condition at 25 DAS. Here, the arrows indicate the adventitious roots.

always try to thrive against waterlogging stress by renovating their vegetative growth, for instance, adventitious root formation. The formation of adventitious root needed high energy used by the plants. Furthermore, plants declined energy for flowering initiation. The delay in days to flowering initiation is a consequence of delay in days to maturing of plants. Moreover, plants faced nutrient deficiency to uptake by the roots as well as adventitious roots from soil and water, which hindered the plants growth as well delayed days to maturity of soybean plants. Khairulina and Tikhonchuk [55] found some dissimilar results in soybean under waterlogging stress. Waterlogged plants took a shorter interstage period than the control plants.

3.5. Yield and Yield-Contributing Parameters. Due to the imposition of waterlogging, the number of pods plant ${ }^{-1}$ was sharply reduced compared to control (Figure 9(a)). The lowest decline in the number of pods plant ${ }^{-1}$ was observed in waterlogged Sohag (5\%) when compared to the control condition. The highest decline in the number of pods plant ${ }^{-1}$ was observed in waterlogged SGB-1 (37\%) in comparison with the control condition. Upon exposure to waterlogging, the reduction in the number of pods plant ${ }^{-1}$ ranged between 10 and $35 \%$ in other genotypes in comparison with the control plants.

When subjected to waterlogging stress, in response, plants showed a reduction of the number of seeds pod ${ }^{-1}$ in contrast to control (Figure 9(b)). The lowest reduction in the number seeds of pod $^{-1}$ was observed in waterlogged Sohag (1\%) and the highest BINAsoybean-5 (9\%) in comparison with the control condition. Upon exposure to waterlogging, the reduction ranged between 3 and $8 \%$ in other genotypes in comparison with their control plants.

When the plants were subjected to waterlogging stress, 100 -seed weight decreased in comparison to the control condition. The lowest reduction in 100-seed weight was observed in waterlogged GC-840 (5\%) followed by BARI Soybean-5 (8\%) and Sohag (9\%). The highest reduction was 


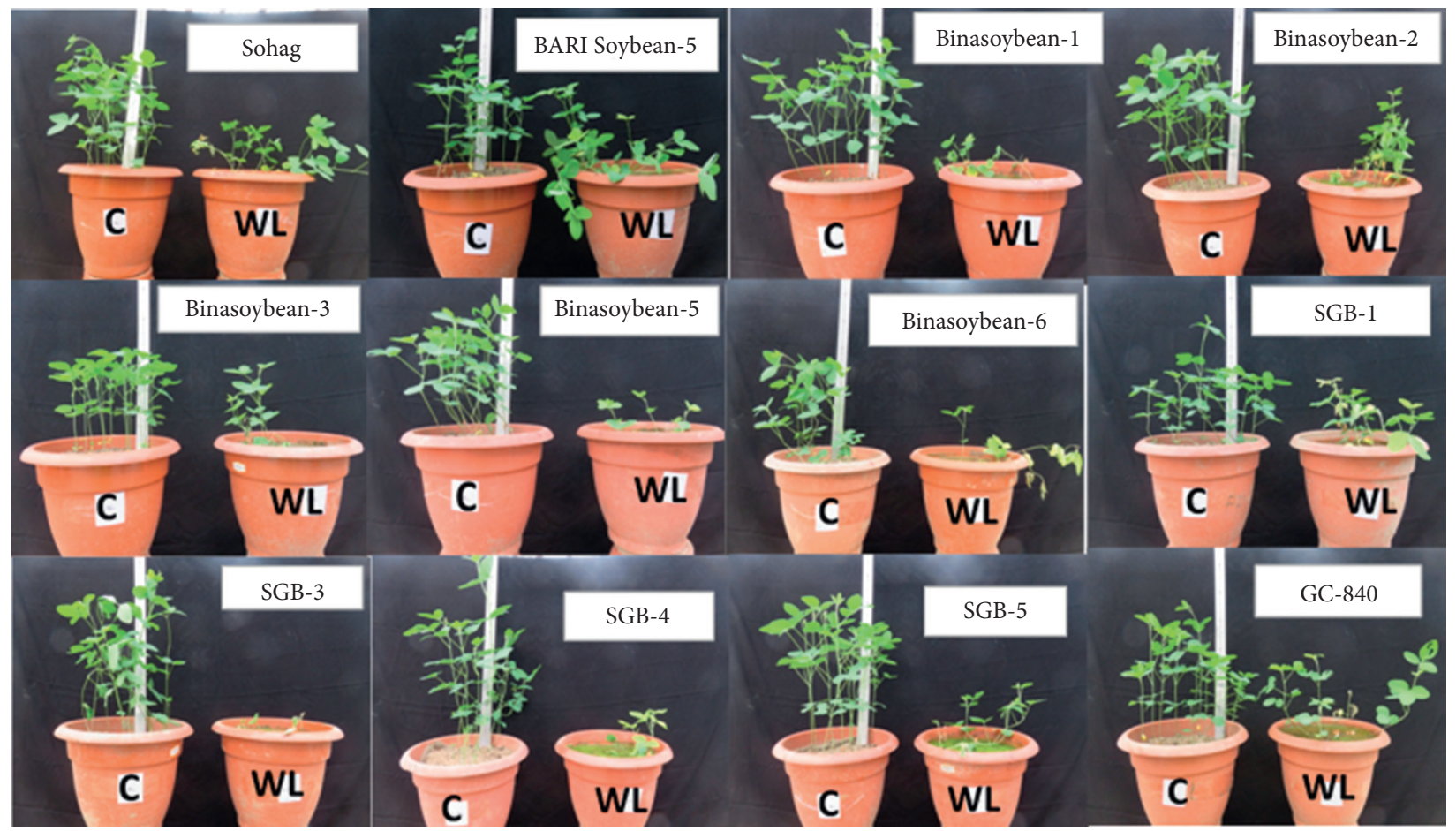

Figure 7: Phenotypic variations of soybean under waterlogged and control condition at 25 DAS. Here, C denotes control and WL waterlogged plants.

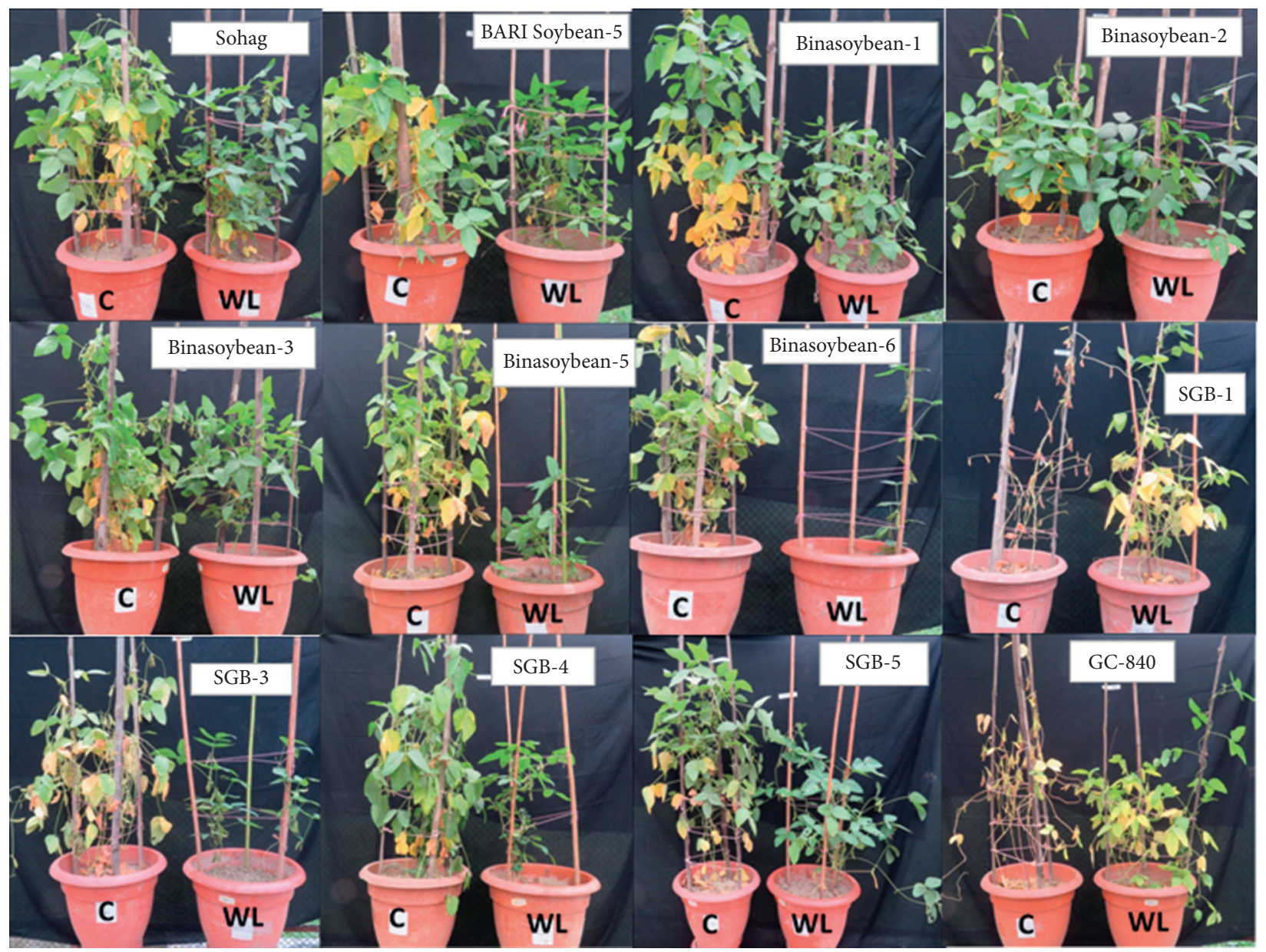

FIgURE 8: Phenotypic variations of soybean under waterlogged and control condition at 75 DAS. Here, C denotes control and WL waterlogged plants. 


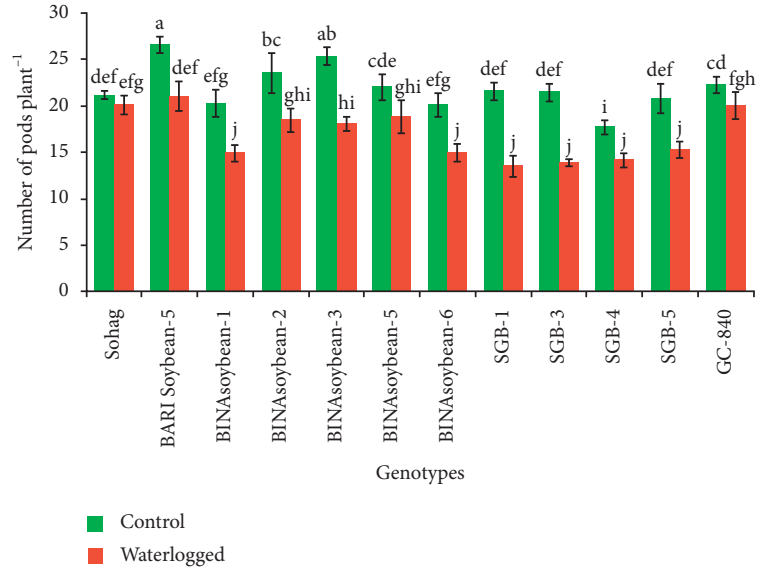

(a)

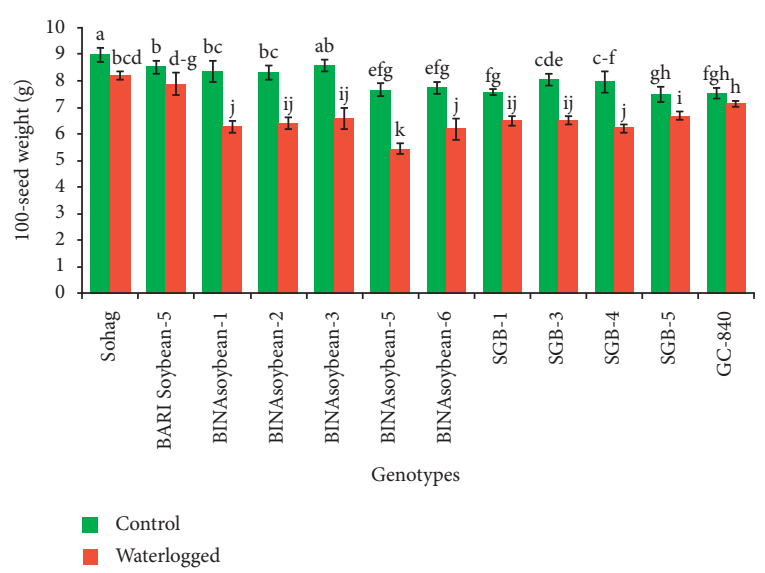

(c)

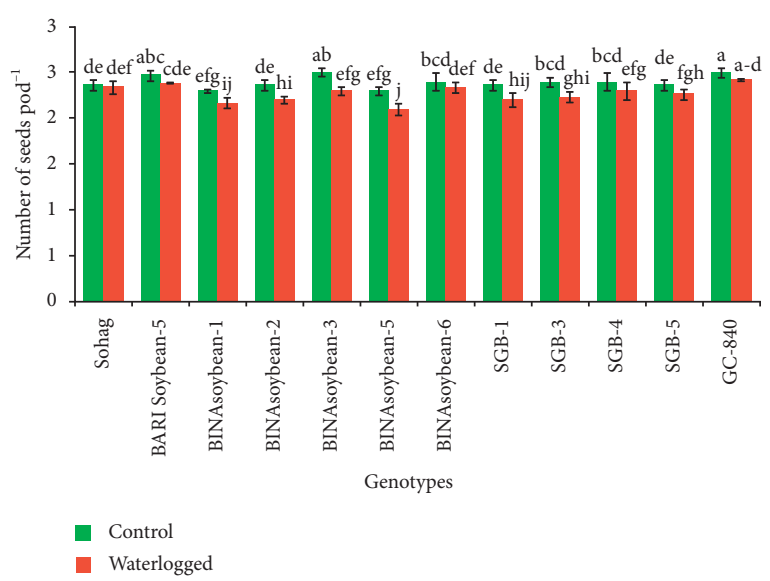

(b)

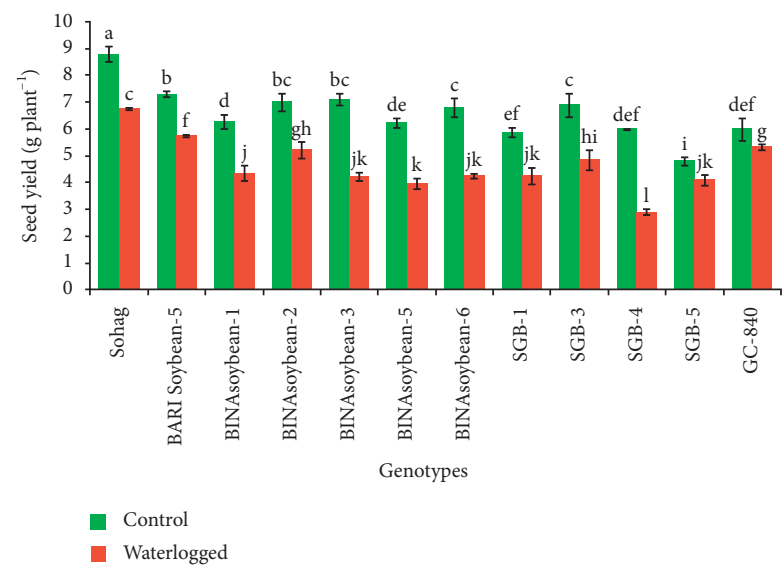

(d)

Figure 9: Effect of waterlogging stress on the number of pods plant ${ }^{-1}$ (a), number of seeds pod ${ }^{-1}$ (b), 100-seed weight, (c) and seed yield plant $^{-1}(\mathrm{~d})$ of different soybean genotypes. For each treatment, the mean $( \pm \mathrm{SD})$ was determined from three replicates. Different alphabets on the bars indicate significant difference at $P \leq 0.05$ after mean comparison by Fisher's LSD test.

in waterlogged BINAsoybean-5 (29\%) in comparison with the control condition. The reduction ranged between 11 and $25 \%$ (Figure 9(c)) in other genotypes when compared with their respective control plants.

Upon exposure to waterlogging, stress seed yield plant ${ }^{-1}$ decreased in comparison to the control condition (Figure 9(d)). The lowest reduction in seed yield was observed in waterlogged GC-840 (11\%) followed by SGB-5 (15\%), BARI Soybean-5 (21\%), and Sohag (23\%). The highest reduction in seed yield was observed in waterlogged SGB-4 (51\%) in comparison with the control condition. Upon exposure to waterlogging, the reduction in seed yield ranged between 28 and $40 \%$ in other genotypes when compared with their respective control plants. A seed is the most crucial element as it is intimately related to seed yield plant $^{-1}$, where seed yield plant ${ }^{-1}$ is affected due to variation of yield in soybean [56]. Primarily under waterlogging conditions, seed yield decreased due to the reduction of number of pods plant ${ }^{-1}$ and pod setting. Kuswantoro [53] observed that sensitive genotypes of soybean bear the least number of pods plant $^{-1}$ than the tolerant one under waterlogging stress. Generally, two or three grains are filled in a pod, whereas this author found that the pods were filled with 1 or 2 seeds, which specified the production of seeds were not accomplished well under flooding stress. Least number of pods plant ${ }^{-1}$ leads to least number of seeds pod $^{-1}$ which ultimately reduced 100-seed weight and seed yield plant $^{-1}$. Branch numbers were correlated to pod number increase [57]. A similar decrease in plant yield has been reported in soybean $[24,38,58,59]$. In addition, yield reduced significantly, and the reduction was greater in waterlogged-sensitive genotypes than the waterlogged-tolerant genotypes of soybean [3], which exhibits that waterlogging has varied responses towards different genetic backgrounds [60].

3.6. Correlation among the Parameters. From the correlation matrix study, it is clear that the mortality rate and electrolyte leakage were negatively correlated $(P \leq 0.05)$ with most of the parameters (Table 2). The stress markers like MDA, $\mathrm{H}_{2} \mathrm{O}_{2}$, and EL were negatively correlated with the growth, physiological, yield, and yield contributing parameters $[1,34]$. 
TABLE 2: Correlation matrix of different parameters activities observed in different soybean genotypes under waterlogging stress condition.

\begin{tabular}{|c|c|c|c|c|c|c|c|c|c|c|c|c|c|}
\hline Variables & $\begin{array}{l}\text { Plant } \\
\text { height }\end{array}$ & $\begin{array}{l}\text { No. of } \\
\text { leaves }\end{array}$ & $\begin{array}{c}\text { No. of } \\
\text { branches }\end{array}$ & $\begin{array}{c}\text { Fresh } \\
\text { weight }\end{array}$ & $\begin{array}{c}\text { Dry } \\
\text { weight }\end{array}$ & $\begin{array}{l}\text { SPAD } \\
\text { value }\end{array}$ & $\begin{array}{c}\text { Relative } \\
\text { water } \\
\text { content }\end{array}$ & $\begin{array}{l}\text { Electrolyte } \\
\text { leakage }\end{array}$ & $\begin{array}{l}\text { Leaf } \\
\text { area }\end{array}$ & $\begin{array}{c}\text { Pod } \\
\text { plant }^{-1}\end{array}$ & $\begin{array}{l}\text { Seeds } \\
\text { pod }^{-1}\end{array}$ & $\begin{array}{c}100- \\
\text { seed } \\
\text { weight }\end{array}$ & $\begin{array}{l}\text { Seed } \\
\text { yield }\end{array}$ \\
\hline $\begin{array}{l}\text { Plant } \\
\text { height }\end{array}$ & 1 & $0.219^{\mathrm{ns}}$ & $0.355^{*}$ & $0.574^{*}$ & $0.379^{*}$ & $0.467^{*}$ & $0.296^{*}$ & $-0.203^{\mathrm{ns}}$ & $-0.046^{\mathrm{ns}}$ & $0.394^{*}$ & $0.417^{*}$ & $0.332^{*}$ & $0.319^{*}$ \\
\hline $\begin{array}{l}\text { No. of } \\
\text { leaves }\end{array}$ & & 1 & $0.426^{*}$ & $0.359^{*}$ & $\begin{array}{c}0.179 \\
\text { ns }\end{array}$ & $0.280^{*}$ & $0.278^{*}$ & $-0.300^{*}$ & $0.486^{*}$ & $0.321^{*}$ & $0.103^{\text {ns }}$ & $0.348^{*}$ & $0.309^{*}$ \\
\hline $\begin{array}{l}\text { No. of } \\
\text { branches }\end{array}$ & & & 1 & $0.621^{*}$ & $0.311^{*}$ & $0.426^{*}$ & $0.589^{*}$ & $-0.542^{*}$ & $-0.060^{\mathrm{ns}}$ & $0.859^{*}$ & $0.547^{*}$ & $0.725^{*}$ & $0.785^{*}$ \\
\hline $\begin{array}{l}\text { Fresh } \\
\text { weight }\end{array}$ & & & & 1 & $0.691^{*}$ & $0.634^{*}$ & $0.652^{*}$ & $-0.687^{*}$ & $0.168^{\mathrm{ns}}$ & $0.616^{*}$ & $0.632^{*}$ & $0.748^{*}$ & $0.707^{*}$ \\
\hline Dry weight & & & & & 1 & $0.688^{*}$ & $0.403^{*}$ & $-0.550^{*}$ & $0.148^{\mathrm{ns}}$ & $0.305^{*}$ & $0.538^{*}$ & $0.445^{*}$ & $0.354^{*}$ \\
\hline $\begin{array}{l}\text { SPAD } \\
\text { value }\end{array}$ & & & & & & 1 & $0.483^{*}$ & $-0.394^{*}$ & $0.027^{\mathrm{ns}}$ & $0.360^{*}$ & $0.477^{*}$ & $0.518^{*}$ & $0.445^{*}$ \\
\hline $\begin{array}{l}\text { Relative } \\
\text { water } \\
\text { content }\end{array}$ & & & & & & & 1 & $-0.324^{*}$ & $0.142^{\mathrm{ns}}$ & $0.508^{*}$ & $0.249^{*}$ & $0.544^{*}$ & $0.679^{*}$ \\
\hline $\begin{array}{l}\text { Electrolyte } \\
\text { leakage }\end{array}$ & & & & & & & & 1 & $\underset{\mathrm{ns}}{-0.056}$ & $-0.633^{*}$ & $-0.534^{*}$ & $-0.726^{*}$ & $-0.632^{*}$ \\
\hline Leaf area & & & & & & & & & 1 & $-0.156^{\mathrm{ns}}$ & $0.012^{\mathrm{ns}}$ & $0.205^{\mathrm{ns}}$ & $0.151^{\mathrm{ns}}$ \\
\hline Pod plant $^{-1}$ & & & & & & & & & & 1 & $0.590^{*}$ & $0.710^{*}$ & $0.720^{*}$ \\
\hline $\begin{array}{l}\text { Seeds } \\
\text { pod }^{-1}\end{array}$ & & & & & & & & & & & 1 & $0.625^{*}$ & $0.543^{*}$ \\
\hline $\begin{array}{l}100 \text {-seed } \\
\text { weight }\end{array}$ & & & & & & & & & & & & 1 & $0.878^{*}$ \\
\hline Seed yield & & & & & & & & & & & & & 1 \\
\hline
\end{tabular}

Here, ${ }^{*}$ significant at $P \leq 0.05$; ns $=$ nonsignificant.

\section{Conclusion}

Soybean crops are usually intolerant to waterlogging stress. By considering all the above-mentioned results, it can be concluded that waterlogging remarkably reduced the growth and yield of all the soybean genotypes when compared with their respective control plants. Among the 12 genotypes, Sohag, BARI Soybean-5, GC-840, BINAsoybean-1, and BINAsoybean-2 performed better than other genotypes under waterlogging. The genotypes SGB-1, SGB-3, SGB-4, SGB-5, BINAsoybean-5, and BINAsoybean-6 did not perform well under waterlogged conditions.

\section{Data Availability}

All data are included within the manuscript.

\section{Conflicts of Interest}

The authors declare that they have no conflicts of interest regarding the publication of this paper.

\section{Acknowledgments}

The authors are grateful to Dr. Hasan Latif, Senior Assistant Director, Bangladesh Agricultural Development Corporation, and Dr. Md. Motiar Rohman, Senior Scientific Officer, Plant Breeding Division, Bangladesh Agricultural Research Institute, for their cooperation in collecting plant materials. This work was conducted with the financial support of Shere-Bangla Agricultural University Research System and Ministry of Science and Technology.

\section{References}

[1] M. Hasanuzzaman, J. A. Mahmud, T. I. Nahar, and M. T. Islam, "Drought stress tolerance in wheat: omics approaches in understanding and enhancing antioxidant defense," in Abiotic Stress-Mediated Sensing and Signaling in Plants: An Omics Perspective, S. M. Zargar, Ed., Springer, New York, NY, USA, 2018.

[2] R. Ara, M. A. Mannan, Q. A. Khaliq, and M. M. Uddin Miah, "Waterlogging tolerance of soybean," Bangladesh Agronomy Journal, vol. 18, no. 2, pp. 105-109, 2015.

[3] C. Wu, A. Zeng, P. Chen et al., "An effective field screening method for flood tolerance in Soybean," Plant Breeding, vol. 136, no. 5, pp. 710-719, 2017.

[4] F. Alizadeh-vaskasi, H. Pirdashti, A. Cherati Araei, and S. Saadatmand, "Waterlogging effects on some antioxidant enzymes activities and yield of three wheat promising lines," Acta Agriculturae Slovenica, vol. 111, no. 3, pp. 621-631, 2018.

[5] S. Duhan, A. Kumari, S. Bala, N. Sharma, and S. Sheokand, "Effects of waterlogging, salinity and their combination on stress indices and yield attributes in pigeonpea (Cajanus cajan L. Millsp.) genotypes," Indian Journal of Plant Physiology, vol. 23, no. 1, pp. 65-76, 2018.

[6] Y.-H. Kim, S.-J. Hwang, M. Waqas et al., "Comparative analysis of endogenous hormones level in two soybean (Glycine max L.) lines differing in waterlogging tolerance," Frontiers of Plant Science, vol. 6, p. 714, 2015.

[7] J. Bailey-Serres, T. Fukao, D. J. Gibbs et al., "Making sense of low oxygen sensing," Trends in Plant Science, vol. 17, no. 3, pp. 129-138, 2012.

[8] L. H. Wegner, "Oxygen Transport in Waterlogged Plants," in Waterlogging Signalling and Tolerance in Plants, S. Mancuso and S. Shabala, Eds., Springer, Berlin, Germany, 2010. 
[9] B. G. Tamang, J. O. Magliozzi, M. A. Maroof, and T. Fukao, "Physiological and transcriptomic characterization of submergence and reoxygenation responses in soybean seedlings," Plant, Cell \& Environment, vol. 37, pp. 2350-2365, 2014.

[10] M. Hasanuzzaman, K. Nahar, A. Rahman, J. A. Mahmud, M. S. Hossain, and M. Fujita, "Soybean production and environmental stresses," in Environmental Stresses in Soybean Production, M. Miransari, Ed., Academic, New York, NY, USA, 2016.

[11] M. Hasanuzzaman, J. Al Mahmud, K. Nahar, T. I. Anee, H. Oku, and M. Fujita, "Responses, adaptation, and ROS metabolism in plants exposed to waterlogging stress," in Reactive Oxygen Species and Antioxidant Systems: Role and Regulation under Abiotic Stress, M. I. R. Khan, N. A. Khan, and A. M. Ismail, Eds., Springer, Singapore, 2017.

[12] L. A. C. J. Voesenek and J. Bailey-Serres, "Flood Adaptive Traits and Processes: A Review," New Phytologist, vol. 206, 2015.

[13] N. A. Anjum, A. Sofo, A. Scopa et al., "Lipids and proteinsmajor targets of oxidative modifications in abiotic stressed plants," Environmental Science and Pollution Research, vol. 22, no. 6, pp. 4099-4121, 2015.

[14] M. Tougou, A. Hashiguchi, K. Yukawa et al., "Responses to flooding stress in soybean seedlings with the alcohol dehydrogenase transgene," Plant Biotechnology, vol. 29, no. 3, pp. 301-305, 2012.

[15] S. Komatsu, D. Thibaut, S. Hiraga et al., "Characterization of a novel flooding stress-responsive alcohol dehydrogenase expressed in soybean roots," Plant Molecular Biology, vol. 77, no. 3, pp. 309-322, 2011.

[16] D. M. Oosterhuis, H. D. Scott, R. E. Hampton, and S. D. Wullschleger, "Physiological responses of two soybean [Glycine max (L.) Merr] cultivars to short-term flooding," Environmental and Experimental Botany, vol. 30, no. 1, pp. 85-92, 1990.

[17] T. I. Anee, Morpho-physiological, Yield and Oxidative Stress Responses of Sesame under Waterlogging Stress, M. S. Thesis, Dept. Agron., Sher-e-Bangla Agricultural University, Dhaka, Bangladesh, 2016.

[18] H. Barrs and P. Weatherley, "A re-examination of the relative turgidity technique for estimating water deficits in leaves," Australian Journal of Biological Sciences, vol. 15, no. 3, pp. 413-428, 1962.

[19] Y. Zhang, L. Wang, Y. Zhang, Q. Wei, and W. Zhang, "Nitric oxide enhances salt tolerance in maize seedlings through increasing activities of proton-pump and $\mathrm{Na}+/ \mathrm{H}+$ antiport in the tonoplast," Planta, vol. 224, no. 3, pp. 545-555, 2006.

[20] CoHort Software, 798 Lighthouse Ave, PMB 320, CoStatStatistics Software Version 6.400, Monterey, CA, USA, 2008.

[21] Statistical Package for Social Sciences Version 27.0, IBM SPSS Statistics for Windows, IBM Crop, Armonk, NY, USA, 2020.

[22] Y. Kim, C. W. Seo, and A. L. Khan, "Ethylene mitigates waterlogging stress by regulating glutathione biosynthesisrelated transcripts in soybeans," bioRxiv, 2018.

[23] M. B. Jackson and B. Ricard, "Physiology, biochemistry and molecular biology of plant root systems subjected to flooding of the soil," in Root Ecology, H. de Kroon and E. J. W. Visser, Eds., Springer, Berlin, Germany, 2003.

[24] M. D. Rhine, G. Stevens, G. Shannon, A. Wrather, and D. Sleper, "Yield and nutritional responses to waterlogging of soybean cultivars," Irrigation Science, vol. 28, no. 2, pp. 135-142, 2010.

[25] V. Ezin, R. D. L. Pena, and A. Ahanchede, "Flooding tolerance of tomato genotypes during vegetative and reproductive stages," Brazilian Journal of Plant Physiology, vol. 22, no. 2, pp. 131-142, 2010.

[26] K. Miura, A. Ogawa, K. Matsushima, and H. Morita, "Root and shoot growth under flooded soil in wild groundnut (Glycine soja) as a genetic resource of waterlogging tolerance for soybean (Glycine max)," Pakistan Journal of Weed Science Research, vol. 18, pp. 427-433, 2012.

[27] S. Akram, M. N. Siddiqui, B. M. N. Hussain et al., "Exogenous glutathione modulates salinity tolerance of soybean [Glycine $\max ($ L.) Merrill] at reproductive stage," Journal of Plant Growth Regulation, vol. 36, no. 4, pp. 877-888, 2017.

[28] A. El-Sabagh, S. Sorour, and A. Ueda, "Evaluation of salinity stress effects on seed yield and quality of three soybean cultivars," Azarian Journal of Agriculture, vol. 2, no. 5, pp. 138-141, 2015.

[29] M. Hamayun, A. Hussain, S. A. Khan et al., "Kinetin modulates physio-hormonal attributes and isoflavone contents of soybean grown under salinity stress," Frontiers of Plant Science, vol. 6, p. 377, 2015.

[30] T. Pedó, F. Koch, and E. G. Martinazzo, "Physiological attributes, growth and expression of vigor in soybean seeds under soil waterlogging," African Journal of Agricultural Research, vol. 10, no. 39, pp. 3791-3797, 2015.

[31] J. T. Youn, K. Van, and J. E. Lee, "Waterlogging effects on nitrogen accumulation and $\mathrm{N}_{2}$ fixation of super nodulating soybean mutants," Journal of Crop Science and Biotechnology, vol. 11, pp. 111-118, 2008.

[32] P. Kumar, M. Pal, R. Joshi, and R. K. Sairam, "Yield, growth and physiological responses of mung bean [Vigna radiata (L.) Wilczek] genotypes to waterlogging at vegetative stage," Physiology and Molecular Biology of Plants, vol. 19, no. 2, pp. 209-220, 2013.

[33] G. Zhang, K. Tanakamaru, J. Abe, and S. Morita, "Influence of waterlogging on some anti-oxidative enzymatic activities of two barley genotypes differing in anoxia tolerance," Acta Physiologiae Plantarum, vol. 29, no. 2, pp. 171-176, 2007.

[34] T. I. Anee, K. Nahar, A. Rahman et al., "Oxidative damage and antioxidant defense in Sesamum indicum after different waterlogging durations," Plants, vol. 8, no. 7, p. 196, 2019.

[35] R. R. Saha, F. Ahmed, and N. Mokarroma, "Physiological and biochemical changes in waterlog tolerant sesame genotypes," SAARC Journal of Agriculture, vol. 14, no. 2, pp. 31-45, 2016.

[36] Y. L. Prasanna and G. R. Rao, "Effect of waterlogging on growth and seed yield in green gram genotypes," International Journal of Food, Agriculture \& Veterinary Sciences, vol. 4, pp. 124-128, 2014.

[37] K. H. Kim, M. J. Cho, J.-M. Kim et al., "Growth response and developing simple test method for waterlogging stress tolerance in soybean," Journal of Crop Science and Biotechnology, vol. 22, no. 4, pp. 371-378, 2019.

[38] A. N. Beutler, R. Giacomeli, and C. M. Albertom, "Soil hydric excess and soybean yield and development in Brazil," Australian Journal of Crop Science, vol. 8, pp. 1461-1466, 2014.

[39] B. Ren, J. Zhang, X. Li et al., "Effects of waterlogging on the yield and growth of summer maize under field conditions," Canadian Journal of Plant Science, vol. 94, no. 1, pp. 23-31, 2014.

[40] M. A. Ashraf, "Waterlogging stress in plants: a review," African Journal of Agricultural Research, vol. 7, no. 13, pp. 1976-1981, 2012.

[41] A. Khan, D. K. Y. Tan, M. Z. Afridi et al., "Nitrogen fertility and abiotic stresses management in cotton crop: a review," Environmental Science and Pollution Research, vol. 24, no. 17, pp. 14551-14566, 2017. 
[42] X. Zhang, Y. Fan, S. Shabala et al., "A new major-effect QTL for waterlogging tolerance in wild barley (H. spontaneum)," Theoretical and Applied Genetics, vol. 130, no. 8, pp. 15591568, 2017.

[43] L. Tian, J. Li, W. Bi et al., "Effects of waterlogging stress at different growth stages on the photosynthetic characteristics and grain yield of spring maize (Zea mays L.) under field conditions," Agricultural Water Management, vol. 218, pp. 250-258, 2019.

[44] M. Amin, M. Karim, Q. Khaliq, M. Islam, and S. Aktar, "Screening of mungbean genotypes for tolerance to waterlogging under field condition," Bangladesh Journal of Agricultural Research, vol. 40, no. 3, pp. 513-519, 2015.

[45] R. N. Mutava, S. J. K. Prince, N. H. Syed et al., "Understanding abiotic stress tolerance mechanisms in soybean: a comparative evaluation of soybean response to drought and flooding stress," Plant Physiology and Biochemistry, vol. 86, pp. 109120, 2015.

[46] N. Katerji, J. W. Van Hoorn, A. Hamdy, M. Mastrorilli, and E. M. Karzel, "Osmotic adjustment of sugar beets in response to soil salinity and its influence on stomatal conductance, growth and yield," Agricultural Water Management, vol. 34, no. 1, pp. 57-69, 1997.

[47] C. A. Jaleel, R. Gopi, P. Manivannan, and R. Panneerselvam, "Responses of antioxidant defense system of Catharanthus roseus (L.) G. Don. to paclobutrazol treatment under salinity," Acta Physiologiae Plantarum, vol. 29, no. 3, pp. 205-209, 2007.

[48] D. Kumutha, K. Ezhilmathi, R. K. Sairam, G. C. Srivastava, P. S. Deshmukh, and R. C. Meena, "Waterlogging induced oxidative stress and antioxidant activity in pigeonpea genotypes," Biologia Plantarum, vol. 53, no. 1, pp. 75-84, 2009.

[49] B. Valliyodan, T. Van Toai, J. Alves et al., "Expression of rootrelated transcription factors associated with flooding tolerance of soybean (Glycine max)," International Journal of Molecular Sciences, vol. 15, no. 10, pp. 17622-17643, 2014.

[50] B. Valliyodan, H. Ye, L. Song, M Murphy, J. G Shannon, and H. T Nguyen, "Genetic diversity and genomic strategies for improving drought and waterlogging tolerance in soybeans," Journal of Experimental Botany, vol. 68, no. 8, pp. 1835-1849, 2017.

[51] M. Bacanamwo and L. C. Purcell, "Soybean root morphological and anatomical traits associated with acclimation to flooding," Crop Science, vol. 39, no. 1, pp. 143-149, 1999.

[52] D. Yin, S. Chen, F. Chen, Z. Guan, and W. Fang, "Morphological and physiological responses of two chrysanthemum cultivars differing in their tolerance to waterlogging," Environmental and Experimental Botany, vol. 67, no. 1, pp. 87-93, 2009.

[53] H. Kuswantoro, "Agronomical characters of some soybean germplasm under waterlogging condition," Journal of Agronomy, vol. 14, no. 2, pp. 93-97, 2015.

[54] Balitkabi, Description of Superior Varieties of Legume and Tuber Crops, Indonesian Legume and Tuber Crops Research Institute, Indonesian, 2012.

[55] T. P. Khairulina and P. V. Tikhonchuk, "Growth and development of soybean under the effect of water stressor," Russian Agricultural Sciences, vol. 38, pp. 364-366, 2012.

[56] S. Kobraee and K. Shamsi, "Evaluation of soybean yield under drought stress by path analysis," Australian Journal of Basic and Applied Sciences, vol. 5, no. 10, pp. 890-895, 2011.

[57] T. Koyama, M. Suenaga, and R. Takeshima, "Growth and yield response of common buckwheat (Fagopyrum esculentum Moench) to waterlogging at different vegetative stages," Plant Production Science, vol. 22, no. 4, pp. 456-464, 2019.
[58] S. Miao, H. Shi, and J. Jian, "Effects of short-term drought and flooding on soybean nodulation and yield at key nodulation stage under pot culture," Journal of Food Agriculture and Environment, vol. 10, pp. 819-824, 2012.

[59] G. Mustafa and S. Komatsu, "Quantitative proteomics reveals the effect of protein glycosylation in soybean root under flooding stress," Frontiers of Plant Science, vol. 5, p. 627, 2014.

[60] Y. Jitsuyama, "Responses of Japanese soybeans to hypoxic condition at rhizosphere were different depending upon cultivars and ambient temperatures," American Journal of Plant Sciences, vol. 4, no. 6, pp. 1297-1308, 2013. 